\title{
A Framework for Assessing the Feasibility of Native Fish Conservation Translocations: Applications to Threatened Bull Trout
}

\author{
Authors: Benjamin T. Galloway, Clint C. Muhlfeld, \\ Christopher S. Guy, Christopher C. Downs \& Wade \\ A. Fredenberg
}

This is an Accepted Manuscript of an article published in North American Journal of Fisheries Management on July 2016, available online:

http://www.tandfonline.com/10.1080/02755947.2016.1146177.

Benjamin T. Galloway, Clint C. Muhlfeld, Christopher S. Guy, Christopher C. Downs \& Wade A. Fredenberg (2016) A Framework for Assessing the Feasibility of Native Fish Conservation Translocations: Applications to Threatened Bull Trout, North American Journal of Fisheries Management, 36:4, 754-768, DOI: 10.1080/02755947.2016.1146177

Made available through Montana State University's $\underline{\text { ScholarWorks }}$ scholarworks. montana.edu 


\title{
A Framework for Assessing the Feasibility of Native Fish Conservation Translocations: Applications to Threatened Bull Trout
}

\author{
Benjamin T. Galloway* \\ Montana Cooperative Fishery Research Unit, Department of Ecology, Montana State University, \\ 301 Lewis Hall, Bozeman, Montana 59717, USA
}

\section{Clint C. Muhlfeld}

U.S. Geological Survey, Northern Rocky Mountain Science Center, Glacier National Park, West Glacier, Montana 59936, USA; and Flathead Lake Biological Station, University of Montana, 32125 Bio Station Lane, Polson, Montana 59860, USA

\section{Christopher S. Guy}

U.S. Geological Survey, Montana Cooperative Fishery Research Unit, Department of Ecology, Montana State University, 301 Lewis Hall, Bozeman, Montana 59717, USA

\section{Christopher C. Downs}

National Park Service, Glacier National Park, West Glacier, Montana 59936, USA

\author{
Wade A. Fredenberg \\ U.S. Fish and Wildlife Service, Creston Fish and Wildlife Center, 780 Creston Hatchery Road, Kalispell, \\ Montana 59901, USA
}

\begin{abstract}
There is an urgent need to consider more aggressive and direct interventions for the conservation of freshwater fishes that are threatened by invasive species, habitat loss, and climate change. Conservation introduction (moving a species outside its indigenous range to other areas where conditions are predicted to be more suitable) is one type of translocation strategy that fisheries managers can use to establish new conservation populations in areas of refugia. To date, however, there are few examples of successful conservation-based introductions. Many attempts fail to establish new populations - in part because environmental factors that might influence success are inadequately evaluated before the translocation is implemented. We developed a framework to assess the feasibility of rescuing threatened fish populations through translocation into historically unoccupied stream and lake habitats. The suitability of potential introduction sites was evaluated based on four major components: the recipient habitat, recipient community, donor population, and future threats. Specific questions were then developed to evaluate each major component. The final assessment was based on a scoring system that addressed each question by using criteria developed from characteristics representative of highly suitable habitats and populations. This framework was used to evaluate the proposed within-drainage translocation of three Bull Trout Salvelinus confluentus populations in Glacier National Park, Montana. Our results indicated that within-drainage translocation is a feasible strategy for conserving locally adapted populations of Bull Trout through the creation of new areas of refugia in Glacier National Park. The framework provides a flexible platform that can help managers make informed decisions for moving threatened fishes into new areas of refugia for conservation and recovery programs.
\end{abstract}


Translocations are increasingly becoming an important management tool for the conservation of native fishes that are threatened by accelerating human stressors, including invasive species, habitat loss, and climate change. Translocation is defined as the human-mediated movement of organisms from one area with release in another (IUCN 2013). Many past attempts at fish translocation have been unsuccessful (Brooks 1985; Hendrickson and Brooks 1991; Harig et al. 2000), likely due in part to an inadequate understanding of all the biotic and abiotic factors that can influence translocation success (Minckley 1995). In many cases, translocations have resulted in severe biological, social, and economic impacts (IUCN 2013). Highlighting the emerging nature of this approach, the International Union for Conservation of Nature (IUCN) published new guidelines and detailed action plans for conservation translocations (IUCN 2013); the guidelines address the full spectrum of translocations, including reintroduction, reinforcement, and conservation introduction. There is an urgent need to develop decision-making frameworks that assist managers in applying more standardized approaches to assessing the feasibility of conservation translocations, thereby maximizing success and avoiding detrimental impacts to native biodiversity.

Conservation introduction is the deliberate, humanmediated movement of organisms to establish new populations in habitats (1) that are not known to have been previously occupied and (2) where conditions are predicted to be more suitable for persistence (IUCN 2013). This approach differs from reintroduction (re-establishment of a species within previously occupied habitats) and reinforcement (restocking of a species to supplement previous translocations; Minckley 1995; IUCN 2013). The IUCN guidelines and other existing guidelines (Williams et al. 1988; Minckley 1995) outline steps for conducting conservation introductions, and they recommend that introductions be restricted to sites where (1) suitable habitat and donor populations exist, (2) other endemic or threatened species will not be extirpated, (3) hybridization is unlikely to occur, (4) the dispersal potential of the species has been identified and deemed acceptable, and (5) all possible threats to the long-term persistence of the population have been identified and are considered acceptable (Williams et al. 1988; Minckley 1995; IUCN 2013).

To date, there have been no published decision-making frameworks to help managers evaluate the feasibility of conservation introductions for freshwater fishes. Moreover, there are few examples in which conservation introductions of fish were used to create new areas of refugia despite the urgent need to implement such actions for threatened species and for populations that face the ongoing threats of habitat loss, invasive species, and climate change. We developed a new and relatively simple framework for evaluating conservation introductions of freshwater fishes; we then used the framework to assess the feasibility of translocating Bull Trout Salvelinus confluentus populations - some of which are threatened with extirpation in the near term - into new areas of refugia within their natal drainages in Glacier National Park, Montana.

This framework builds on the Bull Trout reintroduction framework that was developed by Dunham et al. (2011) by (1) presenting specific criteria with which to evaluate Bull Trout translocation into historically unoccupied habitats (i.e., conservation introduction) and (2) providing thresholds for discriminating between suitable and unsuitable sites. Because Glacier National Park supports a significant proportion of the remaining natural lake habitat within the Bull Trout's range, the present approach has rangewide applicability as a conservation tool for this federally listed species, which is threatened by habitat loss, introductions of invasive species, habitat fragmentation, and climate change (Rieman et al. 1997, 2007). Our specific objectives were to (1) develop a framework that can serve as the basis for assessing the feasibility of conserving threatened freshwater fish populations through their introduction into novel and suitable habitats and (2) use this framework with specific criteria to evaluate the suitability of proposed introduction sites as areas of refugia for the conservation of imperiled Bull Trout in Glacier National Park.

\section{METHODS}

\section{Study Area}

Glacier National Park encompasses approximately $4,100 \mathrm{~km}^{2}$ in the northwestern corner of Montana. Regions of the park drain into three major continental watersheds, including the South Saskatchewan, Missouri, and Columbia River drainages. Subbasins that are situated west of the Continental Divide (Columbia River drainage) are characterized by high-gradient mountain streams that are interspersed with cirque and moraine lakes. Snowmelt drives streamflow in these systems; discharge typically peaks during spring runoff (May-July) and reaches base flow levels in August and September. Stream water temperatures remain cool throughout the year, and maximum August water temperature rarely exceeds $16^{\circ} \mathrm{C}$ (D’Angelo 2010; Jones 2012).

The vast majority of adfluvial Bull Trout populations in western Glacier National Park have dramatically declined in the last 25-30 years due to the invasion and establishment of nonnative Lake Trout Salvelinus namaycush (Fredenberg 2002). Where they have been introduced, Lake Trout consistently displace native Bull Trout through predation and competition (Martinez et al. 2009). Prior to the recent invasion of nonnative Lake Trout, Glacier National Park contained onethird of the remaining natural lakes that supported threatened Bull Trout in the United States. West of the Continental Divide within Glacier National Park, Lake Trout have invaded 9 of the 12 lakes where Bull Trout are native (Fredenberg et al. 2007; D'Angelo and Muhlfeld 2013). In lakes for which data exist, Bull Trout populations have declined to the point of functional extirpation in less than 30 years (Fredenberg 2002; D’Angelo and Muhlfeld 2013; Downs et al. 2013). Thus, 


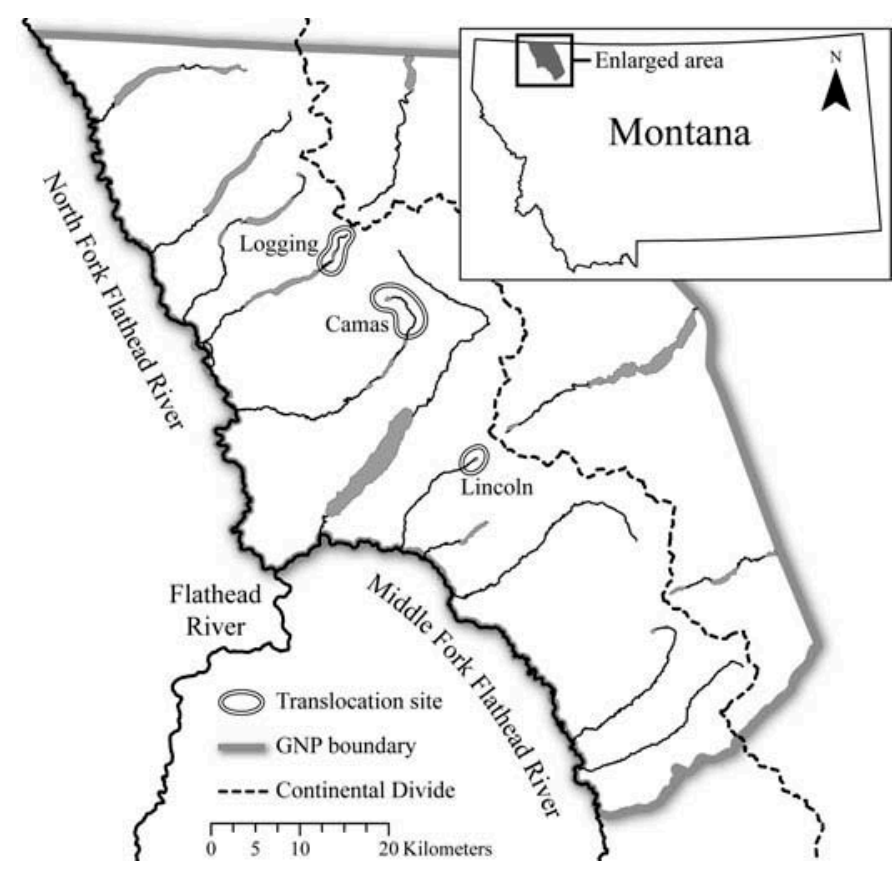

FIGURE 1. Proposed sites of Bull Trout translocation on the west side of the Continental Divide in Glacier National Park, Montana. Translocation sites consisted of stream-and-lake networks within the Logging, Camas, and Lincoln Creek drainages.

managers are considering the translocation of Bull Trout above natural barriers within their natal drainages to conserve and maintain localized ecological and evolutionary processes in the presence of invasive species.

The study sites chosen by managers were located in isolated stream-and-lake networks within the Logging, Camas, and Lincoln Creek drainages of western Glacier National Park (hereafter referred to as the Logging, Camas, and Lincoln sites; Figure 1). These potential recipient sites were selected because (1) Bull Trout populations exist downstream of these sites, providing the possibility of within-drainage translocation; (2) the sites are isolated above natural barriers (e.g., waterfalls) to fish migration, thus preventing future species invasions; and (3) existing trout populations provide evidence that these sites offer physical and biological conditions that may be suitable for Bull Trout persistence.

\section{Framework Development}

We reviewed existing introduction guidelines (Williams et al. 1988; Dunham et al. 2011; IUCN 2013) as the basis to develop a framework for assessing the feasibility of conservation introductions of threatened freshwater fishes. Four major components that influence introduction success were identified: the recipient habitat, recipient community, donor population, and future threats (Figure 2). Specific questions were then developed to evaluate each major component by using criteria that represent characteristics of highly suitable Bull Trout habitats and populations (Table 1).
Criteria were developed by using published data for Bull Trout populations throughout the Columbia River drainage. Past research assessing the relative abundance (Meeuwig and Guy 2007; Meeuwig et al. 2007) and genetic heterozygosity (Meeuwig and Guy 2007; DeHaan et al. 2008, 2010, 2011; Meeuwig et al. 2010; Nyce et al. 2013; Kovach et al. 2015) of Bull Trout populations were referenced to create thresholds for criteria evaluating the donor population. Criteria for the evaluation of water temperatures were developed based on laboratory and field studies that have investigated Bull Trout thermal limits and Bull Trout distribution and abundance relative to water temperature (Fraley and Shepard 1989; Rieman and McIntyre 1993; Saffel and Scarnecchia 1995; Selong et al. 2001; Jones et al. 2014).

A scoring system similar to the one used by Dunham et al. (2011) was developed to rank the relative suitability of proposed sites (Table 1). Each site received a score of 1, 0.5, -0.5, or -1 for criteria used to evaluate habitat quality, the donor population, the biotic community, and future threats (Table 1). A score of 1 indicates that the site is highly suitable for Bull Trout introduction; a score of 0.5 indicates that the site is moderately suitable; and a score of -1 indicates that the site has low suitability. A site was given a score of -0.5 when no information was available for the criterion.

Concurrently, a relative ranking of sites was conducted for criteria that were used to evaluate habitat complexity and habitat quantity (Table 1). Ranking was conducted based on the total amount of habitat that was present within each site. For habitat complexity criteria, ranking was based on the total stream area comprised of each habitat characteristic being evaluated. For habitat quantity criteria, ranking was based on the total amount of stream and lake habitat that was present. The site containing the greatest total area of each habitat characteristic was considered the most suitable and was given a score of 1 for that criterion. The site with the second-greatest amount of total area was given a score of 0.5 , and the site with the lowest amount of total area was given a score of 0 . Scores for all criteria were then added, resulting in an overall score for each site. Sites were ranked, and the site with the greatest overall score was considered most suitable for Bull Trout translocation.

\section{Assessment of the Recipient Habitat}

Each site was evaluated based on the suitability of stream and lake habitat necessary to support Bull Trout growth and survival during spawning, rearing, foraging, migration, and overwintering. Habitat surveys were conducted to determine the quantity and complexity of stream and lake habitats that were present at each site. Mesohabitat characteristics within streams were quantified by use of a modified Hankin and Reeves (1988) habitat analysis; detailed descriptions of sampling procedures are outlined in the original feasibility assessment (Galloway 2014). 


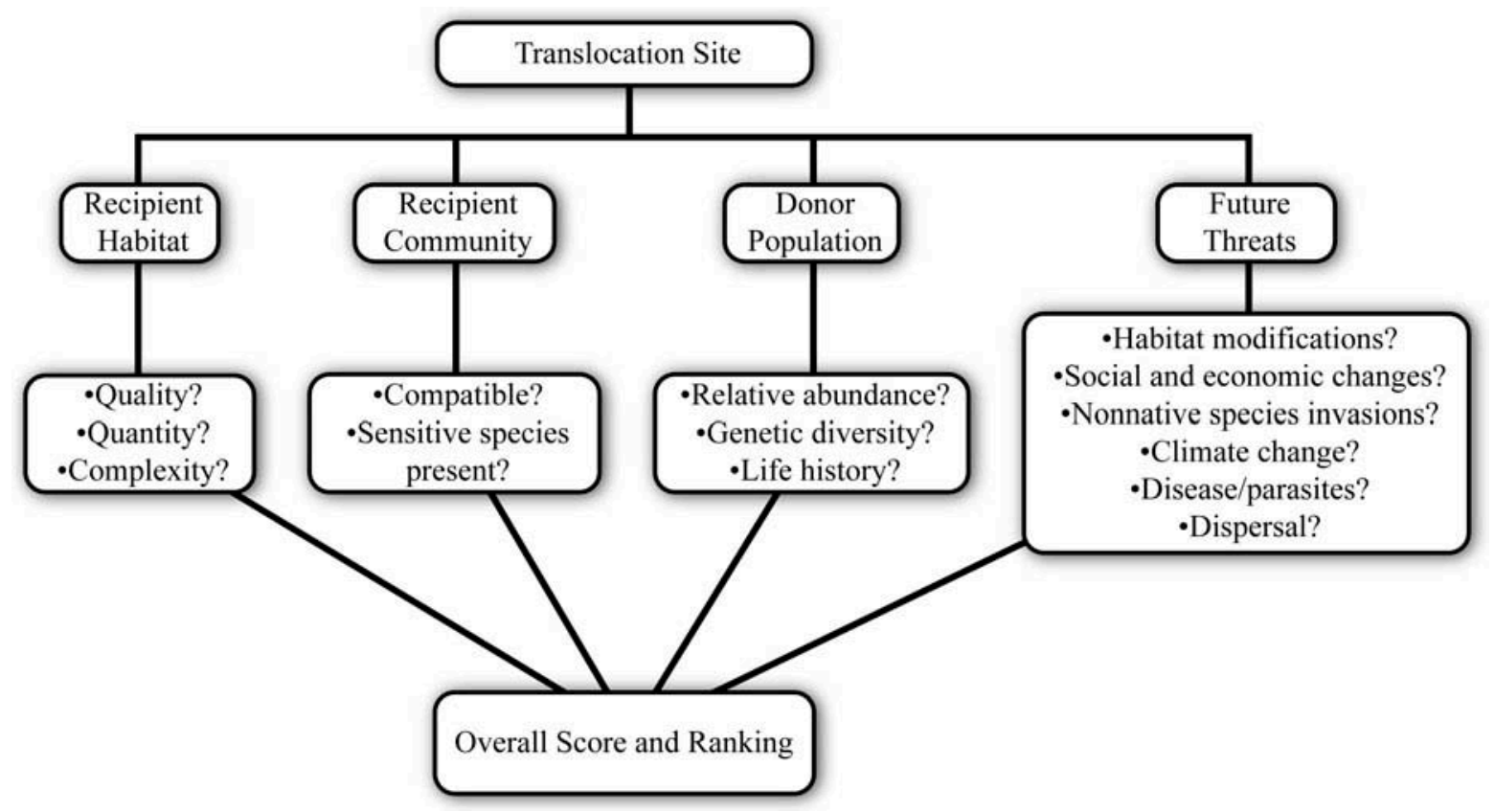

FIGURE 2. Hierarchical framework that was developed to evaluate the feasibility of Bull Trout translocation, including the four major components (recipient habitat, recipient community, donor population, and future threats) and the key questions that were used to evaluate each component.

Is stream habitat quality suitable for Bull Trout introduction?-For Bull Trout, as for many coldwaterdependent salmonids, water temperature is an important determinant of habitat suitability (McPhail and Murray 1979; Dunham et al. 2003; Wenger et al. 2011; Jones et al. 2014; Kovach et al. 2015). Therefore, we evaluated sites by using criteria that were designed to identify habitat that was thermally suitable for rearing, foraging, migration, and overwintering. Baseline models for evaluating Bull Trout thermal habitat within the Flathead River basin suggested that a majority ( $>95 \%$ ) of Bull Trout rearing habitat exists in areas where mean August stream temperature is less than $13^{\circ} \mathrm{C}$ (Jones et al. 2014). Other studies have shown that water temperatures ranging from $13.1^{\circ} \mathrm{C}$ to $15^{\circ} \mathrm{C}$ can provide suitable rearing habitat for juvenile Bull Trout (Selong et al. 2001; Dunham et al. 2003). Furthermore, in a study of the Flathead River basin, Fraley and Shepard (1989) rarely observed juvenile Bull Trout in streams with temperatures exceeding $15^{\circ} \mathrm{C}$.

To determine site suitability, stream temperatures were recorded hourly from August 2011 to September 2012 by using Hobo Pro v2 water temperature data loggers (Onset Computer Corporation, Bourne, Massachusetts) that were anchored to the substrate. Sites were given a score of 1 (highly suitable) if the observed mean August stream temperature was below $13^{\circ} \mathrm{C}$; a score of 0.5 (moderately suitable) if the recorded mean August stream temperature was between $13.1^{\circ} \mathrm{C}$ and $15^{\circ} \mathrm{C}$; a score of -1 (low suitability) if the recorded mean August stream temperature was above $15^{\circ} \mathrm{C}$; or a score of -0.5 if no information was available (Table 1).
Is lake habitat quality suitable for Bull Trout introduction?Lacustrine habitat within each site was evaluated based on the ability to provide thermal refuge for Bull Trout during periods of high stream temperatures in addition to providing suitable foraging, migration, and overwintering habitat. Models evaluating Bull Trout thermal habitat within the Flathead River basin predicted that more than $97 \%$ of foraging, migration, and overwintering habitat exists where mean August water temperatures are less than $14^{\circ} \mathrm{C}$ (Jones et al. 2014). Furthermore, Bull Trout distributional limits are associated with water temperatures that regularly exceed $16^{\circ} \mathrm{C}$ (McPhail and Murray 1979; Dunham et al. 2003).

Lake temperatures were recorded hourly by using Hobo Pro v2 water temperature data loggers from August 2011 to September 2012. A temperature profile was created by fastening loggers to an anchor line at 5-m intervals beginning at the surface and extending to a depth of $30 \mathrm{~m}$. Intervals were reduced in Camas and Grace lakes because maximum depth was less than $30 \mathrm{~m}$. Sites were assigned a score of 1 (highly suitable) if mean August lake temperature was less than or equal to $14^{\circ} \mathrm{C}$ and if maximum lake temperature was less than or equal to $16^{\circ} \mathrm{C}$; a score of 0.5 (moderately suitable) if observed mean August lake temperature was between $14.1^{\circ} \mathrm{C}$ and $15^{\circ} \mathrm{C}$ and if maximum lake temperature was less than or equal to $16^{\circ} \mathrm{C}$; a score of -1 (low suitability) if both criteria were exceeded; or a score of -0.5 if no information was available (Table 1).

Which site has the greatest habitat complexity?-Habitat complexity has been associated with higher Bull Trout 


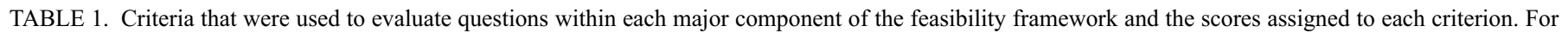

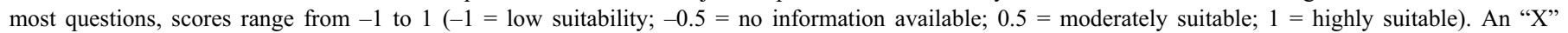

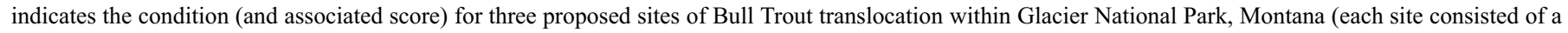

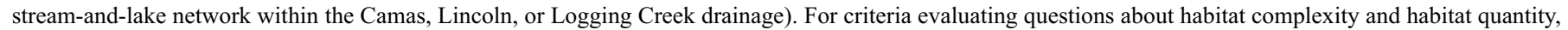

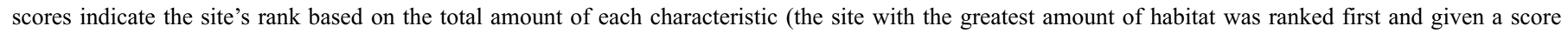
of 1 ; the site with the second-greatest amount was given a score of 0.5 ; and the site with the lowest amount was given a score of 0 ).

Site

Question

Criterion

Site

Question

\section{Major component: recipient habitat}

Is stream habitat quality suitable for Bull Trout?

Mean August stream temperature $\leq 13^{\circ} \mathrm{C}$ 1

Mean August stream temperature $=13.1-15^{\circ} \mathrm{C}$

0.5

No information

$-0.5$

Mean August stream temperature $>15^{\circ} \mathrm{C}$

Is lake habitat quality suitable for Bull Trout?

Mean August lake temperature $\leq 14^{\circ} \mathrm{C}$; maximum lake temperature $\leq 16^{\circ} \mathrm{C}$

Mean August lake temperature $=14.1-15^{\circ} \mathrm{C}$; maximum lake temperature $\leq 16^{\circ} \mathrm{C}$

No information

$-1$

Mean August lake temperature $>15^{\circ} \mathrm{C}$; Score Camas Lincoln Logging maximum lake temperature $>16^{\circ} \mathrm{C}$

Which site has the greatest habitat complexity?

Which site contains the greatest quantity of habitat?

Will introduction have adverse impacts on other sensitive aquatic species?

Is the existing biotic community compatible with Bull Trout?

Is the relative abundance of the donor population suitable?
Total stream area comprised of slow-water habitat units

Total stream area comprised of coarse substrate $(>75 \mathrm{~mm})$

Total stream area comprised of gravel substrate $(20-75 \mathrm{~mm})$

Total stream area comprised of instream cover

Total stream area

Maximum lake depth

Lake surface area

\section{Major component: recipient community}

Threatened, endangered, or sensitive native aquatic species not detected

No information

Threatened, endangered, or sensitive native aquatic species detected

Hybridizing or competing species not detected No information

Hybridizing or competing species detected

\section{Major component: donor population}

Relative abundance estimates $\geq 0.2$ fish/net-hour No information

Relative abundance estimates $<0.2$ fish/net-hour

$\begin{array}{llll}1 & \mathrm{X} & \mathrm{X} & \mathrm{X} \\ 0.5 & & & \\ -0.5 & & & \\ -1 & & & \\ & & & \\ & 1 & 0 & 0.5 \\ & & & \\ & 0.5 & 0 & 1 \\ & & & \\ & 1 & 0 & 0.5 \\ & & & \\ & 0.5 & 0 & 1 \\ & 0.5 & 0 & 1 \\ 0.5 & 1 & 0 \\ 0 & 1 & 0.5\end{array}$

$1+\mathrm{X}$

$-0.5$

$-1 \quad \mathrm{X} \quad \mathrm{X}$

1 X $\quad$ X

$-0.5$

$-1 \quad \mathrm{X}$

$\mathrm{X}$ $-0.5$

$-1$
X

X 


\begin{tabular}{|c|c|c|c|c|c|}
\hline \multirow[b]{2}{*}{ Question } & \multirow[b]{2}{*}{ Criterion } & \multirow[b]{2}{*}{ Score } & \multicolumn{3}{|c|}{ Site } \\
\hline & & & Camas & Lincoln & Logging \\
\hline \multirow{3}{*}{$\begin{array}{l}\text { Is the genetic diversity of the donor } \\
\text { population suitable? }\end{array}$} & Observed genetic heterozygosity $\geq 0.5$ & 1 & & $\mathrm{X}$ & $\mathrm{X}$ \\
\hline & No information & -0.5 & & & \\
\hline & Observed genetic heterozygosity $<0.5$ & -1 & $\mathrm{X}$ & & \\
\hline \multirow{3}{*}{$\begin{array}{l}\text { Is the life history strategy of the } \\
\text { donor population compatible? }\end{array}$} & Yes & 1 & $\mathrm{X}$ & $\mathrm{X}$ & $\mathrm{X}$ \\
\hline & No information & -0.5 & & & \\
\hline & No & -1 & & & \\
\hline \multicolumn{6}{|c|}{ Major component: future threats } \\
\hline \multirow{3}{*}{$\begin{array}{l}\text { Are sites threatened by future } \\
\text { habitat modification? }\end{array}$} & No & 1 & $\mathrm{X}$ & $\mathrm{X}$ & $\mathrm{X}$ \\
\hline & No information & -0.5 & & & \\
\hline & Yes & -1 & & & \\
\hline \multirow{3}{*}{$\begin{array}{l}\text { Are sites threatened by future } \\
\text { social or economic changes? }\end{array}$} & No & 1 & $\mathrm{X}$ & $\mathrm{X}$ & $\mathrm{X}$ \\
\hline & No information & -0.5 & & & \\
\hline & Yes & -1 & & & \\
\hline \multirow{3}{*}{$\begin{array}{l}\text { Are sites threatened by future } \\
\text { nonnative species invasions? }\end{array}$} & No & 1 & $\mathrm{X}$ & $\mathrm{X}$ & $\mathrm{X}$ \\
\hline & No information & -0.5 & & & \\
\hline & Yes & -1 & & & \\
\hline \multirow[t]{4}{*}{$\begin{array}{l}\text { Will sites remain thermally suitable } \\
\text { under future climate change? }\end{array}$} & $\begin{array}{l}\text { Future mean August stream temperature } \\
\text { estimated at }<13^{\circ} \mathrm{C}\end{array}$ & 1 & & $\mathrm{X}$ & \\
\hline & $\begin{array}{l}\text { Future mean August stream temperature } \\
\text { estimated at } 13.1-15^{\circ} \mathrm{C}\end{array}$ & 0.5 & $\mathrm{X}$ & & $\mathrm{X}$ \\
\hline & No information & -0.5 & & & \\
\hline & $\begin{array}{l}\text { Future mean August stream temperature } \\
\text { estimated at }>15^{\circ} \mathrm{C}\end{array}$ & -1 & & & \\
\hline \multirow{3}{*}{$\begin{array}{l}\text { Will disease or parasites impact } \\
\text { introduction success? }\end{array}$} & No & 1 & $\mathrm{X}$ & $\mathrm{X}$ & $\mathrm{X}$ \\
\hline & No information & -0.5 & & & \\
\hline & Yes & -1 & & & \\
\hline \multirow{3}{*}{$\begin{array}{l}\text { Has dispersal potential been } \\
\text { determined and considered } \\
\text { acceptable? }\end{array}$} & $\begin{array}{l}\text { Dispersal outside of the introduction site is } \\
\text { not possible }\end{array}$ & 1 & & & \\
\hline & No information & -0.5 & & & \\
\hline & $\begin{array}{l}\text { Dispersal outside of the introduction site is } \\
\text { possible }\end{array}$ & -1 & $\mathrm{X}$ & $\mathrm{X}$ & $\mathrm{X}$ \\
\hline \multirow{3}{*}{$\begin{array}{l}\text { Has establishment potential been } \\
\text { determined and considered } \\
\text { acceptable? }\end{array}$} & $\begin{array}{l}\text { Establishment of Bull Trout outside of the } \\
\text { introduction site is not possible }\end{array}$ & 1 & $\mathrm{X}$ & $\mathrm{X}$ & $\mathrm{X}$ \\
\hline & No information & -0.5 & & & \\
\hline & $\begin{array}{l}\text { Establishment of Bull Trout outside of the } \\
\text { introduction site is possible }\end{array}$ & -1 & & & \\
\hline
\end{tabular}


densities (Watson and Hillman 1997; Rich et al. 2003), seasonal habitat use (Fraley and Shepard 1989; Muhlfeld and Marotz 2005), and higher levels of genetic diversity (Kovach et al. 2015). Habitat complexity within streams was evaluated by using four criteria that were associated with complex Bull Trout habitat, including slow-water habitats (pools and glides), coarse substrates (cobble and boulder), gravel substrate, and instream cover (i.e., large woody debris, undercut banks, overhanging vegetation, boulders, and backwaters). For each criterion, sites were ranked based on the total stream area comprised of each habitat characteristic being evaluated. The site with the greatest total area for each evaluated characteristic was ranked as the most suitable for that criterion and was given the highest score (Table 1).

Which site contains the greatest quantity of habitat?-The quantity of suitable habitat is also associated with Bull Trout abundance and persistence (Rieman and McIntyre 1995; Dunham and Rieman 1999). The quantity of stream habitat within sites was evaluated by using total stream area as a measure of habitat patch size (Rieman and McIntyre 1995). Sites were ranked according to total stream area, such that the site with the greatest stream area was ranked the most suitable. Similarly, sites were ranked according to the amount of lacustrine habitat available. Sites with the greatest maximum lake depth and surface area were ranked most suitable for introduction (Table 1).

\section{Assessment of the Recipient Community}

Will the introduction have adverse impacts on other sensitive aquatic species?-A major determinant of conservation introduction feasibility is to minimize impacts to other native fauna. Aquatic species introductions can change the composition of the zooplankton, benthic invertebrate, amphibian, and fish communities (Hecnar and M'Closkey 1997; Marnell 1997; Carlisle and Hawkins 1998; Knapp and Matthews 2000; Knapp et al. 2001a; McDowell 2003). Fish introductions can also modify the structure and function of aquatic ecosystems (Knapp et al. 2001b; Eby et al. 2006), and it is likely that the introduction of Bull Trout - an apex predator - into novel environments would alter the food web dynamics at recipient sites. As such, existing protocols recommend prohibiting introductions to sites where sensitive native species could be negatively impacted (Williams et al. 1988; Minckley 1995; IUCN 2013). Community assemblages at each site were assessed via stream and lake shoreline electrofishing, gillnetting, kicknetting, and zooplankton net tows; detailed descriptions of sampling procedures are outlined in the original feasibility assessment (Galloway 2014). Sites were given a score of 1 (highly suitable) if threatened, endangered, or other sensitive native species were not detected during sampling; a score of -1 (low suitability) if such species were detected; or a score of -0.5 if no information was available (Table 1).

Is the existing biotic community compatible with Bull Trout?-Nonnative salmonids have negatively affected the distribution, abundance, and genetic diversity of many Bull
Trout populations through competition, predation, and hybridization (Fredenberg 2002; Rich et al. 2003; Meeuwig et al. 2008; Downs et al. 2013). Introduction to sites where competing or hybridizing species exist is likely to jeopardize the success of the introduction and is strongly discouraged (Williams et al. 1988). Therefore, sites were given a score of 1 (highly suitable) if hybridizing or competing salmonid species were not detected during sampling; a score of -1 (low suitability) if such species were detected; or a score of -0.5 if no information was available (Table 1).

\section{Assessment of the Donor Population}

Conducting an introduction by using propagules from an appropriate donor population is equally important to the success of the introduction (Williams et al. 1988; Dunham et al. 2011). Existing protocol recognizes that selection criteria will vary depending on the overall purpose of the introduction and suggests that priority may lie with the most threatened, most genetically pure, or most geographically proximate population (Williams et al. 1988). With regard to the present study, managers were interested in rescuing within-drainage Bull Trout through introduction into recipient habitats. Therefore, only Bull Trout populations that were located downstream of the proposed introduction sites were evaluated.

Previous reintroduction assessments have recommended the use of Bull Trout donor populations with spawner abundances greater than 1,000 spawning adults/year because the risk to the donor population increases as spawner abundance declines below 1,000 individuals (Dunham et al. 2011). However, Bull Trout populations in Glacier National Park exist at much smaller geographic scales, and spawner abundances do not meet this criterion (Downs et al. 2013). Therefore, we evaluated the relative abundance (represented as fish/net-hour) and genetic diversity (heterozygosity) of donor populations to determine whether those populations contained sufficient numbers and levels of genetic diversity to maximize introduction success and adaptive potential (Allendorf and Leary 1986; Williams et al. 1988; Dunham et al. 2011; Kovach et al. 2015). We also evaluated whether the life history strategy of the donor populations was compatible with the available habitat at proposed introduction sites.

Is the relative abundance of the donor population sufficient?-Thresholds distinguishing suitable sites based on relative abundance were created by using estimates from existing Bull Trout populations in Glacier National Park. Self-sustaining populations that have not been compromised by competing or hybridizing species exhibit relative abundances generally greater than 0.2 fish/net-hour (Meeuwig and Guy 2007; Meeuwig et al. 2007). Previous research was reviewed to determine the relative abundance of Bull Trout populations downstream of the proposed sites (Meeuwig and Guy 2007; Meeuwig et al. 2007). Potential donor populations exhibiting relative abundances greater than 0.2 fish/net-hour were given a score of 1 (highly suitable). 
Potential donor populations that did not meet this criterion were considered to have low suitability and were given a score of -1 . Populations for which no information was available were given a score of -0.5 (Table 1 ).

Is the genetic diversity of the donor population sufficient?There is some debate regarding the appropriateness of using neutral loci as an indicator of evolutionary adaptive potential. Some researchers argue that neutral loci should not be used as an indicator of adaptive potential because neutral genetic markers may not be strongly correlated with fitness and therefore do not represent the adaptive potential of a population (Holderegger et al. 2006). Others have shown that a correlation exists between genetic diversity and population fitness and that higher levels of genetic heterozygosity are associated with higher levels of fitness and evolutionary potential (Allendorf and Leary 1986; Reed and Frankham 2003). Still other researchers have argued that populations with high levels of genetic diversity may exhibit higher levels of adaptive potential in the face of rapid environmental change (Kovach et al. 2015). We evaluated genetic diversity as a way of identifying populations with greater adaptive potential and higher resistance to inbreeding and genetic depression.

To evaluate genetic diversity, we created thresholds for distinguishing suitable donor populations based on heterozygosity estimates calculated for Bull Trout populations elsewhere in the Columbia River basin (DeHaan et al. 2008, 2010, 2011; Nyce et al. 2013; Kovach et al. 2015) and Glacier National Park (Meeuwig and Guy 2007; Meeuwig et al. 2010). Most of the connected populations of Bull Trout (i.e., populations not isolated by dispersal barriers) exhibit genetic heterozygosity estimates that are greater than or equal to 0.5 . We evaluated adaptive potential by referencing previous research that investigated the genetic heterozygosity of Bull Trout populations downstream of the proposed sites (Meeuwig and Guy 2007; Meeuwig et al. 2010). Potential donor populations with genetic heterozygosity estimates greater than or equal to 0.5 were given a score of 1 (highly suitable). Potential donor populations that did not meet this criterion were considered to have low suitability for introduction and were given a score of -1 . Populations with no information available were given a score of -0.5 (Table 1 ).

Is the life history strategy of the donor population compatible? -Equally important to translocation success is the selection of a donor population that exhibits a life history strategy that is compatible with the recipient habitat. Donor populations were evaluated based on their life history strategy (e.g., fluvial, adfluvial, or lacustrine), and sites were scored according to the likelihood that the recipient habitat could support the expressed life history strategy. Sites were given a score of 1 (highly suitable) if they were likely to support the expressed life history strategy of the donor population; a score of -1 (low suitability) if they were unlikely to support the expressed life history strategy of the donor population; or a score of -0.5 if no information was available (Table 1 ).

\section{Assessment of Future Threats}

Conservation introductions are long-term management actions that seek to establish new populations so as to increase a species' likelihood of persistence (IUCN 2013). As such, any framework that informs conservation action should evaluate future threats to the proposed sites. Future threats that could jeopardize translocation success include habitat modifications, social and economic changes, nonnative species invasions, climate change, diseases and parasites, and dispersal.

Are sites threatened by future habitat modifications?Habitat modifications, such as riparian development, land use changes (e.g., mining, logging, grazing, and commercial development), flow modifications, and natural disasters (e.g., fire and floods), have the potential to jeopardize the long-term persistence of populations. Existing guidelines suggest (1) that introductions be restricted to protected sites whenever possible or (2) documenting some form of management agreement with the landowner or land management agency to ensure the site's continued suitability in the future (Williams et al. 1988). Potential future habitat modifications were evaluated for each proposed introduction site. Sites were given a score of 1 (highly suitable) if there were no predictable land use changes that would impact Bull Trout persistence; a score of -1 (low suitability) if predicted land use changes would threaten the persistence of translocated Bull Trout; or a score of -0.5 if no information was available (Table 1).

Are sites threatened by future social or economic changes?Any conservation introduction is likely to have direct and indirect impacts on society (IUCN 2013). Such impacts include changes in harvest regulations and possible economic losses due to restrictions on water allocations, land use, or development. As a result, society will have legitimate interests in any conservation introduction (IUCN 2013), and social and economic interests may conflict with the introduction in the future. Sites were therefore evaluated based on the likelihood that future social and economic changes would impact the long-term success of the introduction. Sites received a score of 1 (highly suitable) if there were no foreseeable social or economic changes that would threaten Bull Trout persistence; a score of -1 (low suitability) if such changes were predicted to occur; or a score of -0.5 if no information was available (Table 1).

Are sites threatened by future nonnative species invasions?Nonnative invasive species have been shown to exert strong impacts on native ecosystems. Negative results stemming from nonnative species invasions (both natural and through human intervention [illegal introductions]) include fish behavioral modifications, population declines from competition and predation, and the loss of genetic purity through hybridization and introgression. As such, proposed introduction sites were evaluated based on the likelihood that nonnative species invasions would threaten the future persistence of Bull Trout. Sites were given a score of 1 (highly suitable) if nonnative species invasions were unlikely; a score of -1 (low suitability) if future nonnative species invasions had a high likelihood of 
occurrence; or a score of -0.5 if no information was available (Table 1).

Will sites remain thermally suitable under future climate change?-Climate warming is predicted to increase water temperatures in freshwater ecosystems worldwide, including aquatic habitats that support Bull Trout populations in Glacier National Park (Jones et al. 2014). These changes are likely to shift the distribution of many aquatic species, including Bull Trout (Rieman et al. 2007; Wenger et al. 2013; Jones et al. 2014). Researchers recently estimated the thermal regimes of Bull Trout and assessed the potential effects of climate warming on critical habitats in the upper Flathead River system (Jones et al. 2014). The model estimated the summer thermal regimes of spawning and rearing habitats at temperatures less than $13^{\circ} \mathrm{C}$ and foraging, migration, and overwintering habitats at temperatures less than $14^{\circ} \mathrm{C}$. We used this spatial hierarchical model to estimate the future mean August stream temperatures for recipient stream habitats (22-m resolution) based on predicted increases in average August air temperatures from 2000 (baseline) to 2035 (RCP 2026-2045; see Jones et al. 2014 for more details). We applied these predicted air temperature increases to streams within each proposed site to determine whether stream habitats would be thermally suitable after predicted increases in air temperature. Sites were given a score of 1 (highly suitable) if mean August stream temperature for all stream habitat was predicted to be below $13^{\circ} \mathrm{C}$; a score of 0.5 (moderately suitable) if mean August stream temperature was predicted to be $13.1-15^{\circ} \mathrm{C}$; a score of -1 (low suitability) if mean August stream temperature was predicted to be greater than $15^{\circ} \mathrm{C}$; or a score of -0.5 if no information was available regarding future thermal suitability (Table 1).

Will disease or parasites impact translocation success?The introduction of new species has the potential to transfer new parasites and diseases to the introduction site. Although this will probably not impact the survival of the introduced species, it can have large negative consequences for native species. Existing guidelines recommend examining the donor stock prior to introduction to determine whether any parasites or diseases are likely to be transferred as a result of the translocation (Williams et al. 1988). Concurrently, diseases and parasites that are present at the proposed introduction site can jeopardize translocation success by threatening individual survival. Proposed sites should be evaluated for disease and parasite presence prior to introduction. Sites were given a score of 1 (highly suitable) if the transfer of new diseases or parasites between the donor site and the introduction site was unlikely; a score of -1 (low suitability) if the transfer of new diseases or parasites between the donor site and the introduction site was likely; or a score of -0.5 if no information was available (Table 1).

Has dispersal potential been determined and considered acceptable? - Introduction of a species outside its native range has the potential to generate unintended negative consequences for native aquatic species and ecosystems (Mueller and Hellmann 2008; Ricciardi and Simberloff 2009; Minteer and Collins 2010). Furthermore, the dispersal of individuals outside of the intended introduction site can decrease the likelihood of establishing a successful population within that site. As such, the dispersal potential of the introduced species should be evaluated to maximize the likelihood of conducting a successful translocation. Sites were assigned two scores for this question: one relating to the possibility that dispersal could jeopardize introduction success, and the other relating to the likelihood that dispersal could lead to the establishment of Bull Trout outside of the introduction site. Sites were given a score of 1 (highly suitable) if dispersal outside of the introduction site was not possible (e.g., due to a natural barrier); a score of -1 (low suitability) if dispersal outside of the introduction site was possible (i.e., connected); or a score of -0.5 if no information was available (Table 1). Concurrently, sites were given a score of 1 (highly suitable) if dispersal was unlikely to lead to Bull Trout establishment outside of the introduction site; a score of -1 (low suitability) if dispersal could lead to Bull Trout establishment outside of the introduction site; or a score of -0.5 if no information was available (Table 1).

\section{RESULTS AND DISCUSSION}

\section{Assessment of the Recipient Habitat}

Is habitat quality suitable for Bull Trout introduction?This question was addressed by using criteria that assessed stream and lake temperatures within sites. Mean August stream temperatures varied from $13.1^{\circ} \mathrm{C}$ to $15^{\circ} \mathrm{C}$ among sites, resulting in a score of 0.5 (moderate suitability) for each site (Table 1). Although not within the range for thermally suitable juvenile Bull Trout rearing habitat as estimated by Jones et al. (2014), the observed stream temperatures were within the range shown by others to provide suitable rearing habitat for Bull Trout (Selong et al. 2001; Dunham et al. 2003).

The second criterion evaluated lacustrine habitat based on the ability to provide refuge during periods of high stream temperature and the presence of thermally suitable habitat for Bull Trout foraging, migration, and overwintering. Mean August lake temperatures were below $14^{\circ} \mathrm{C}$ and maximum lake temperatures did not exceed $16^{\circ} \mathrm{C}$ at all sites, resulting in a score of 1 (high suitability) for each site (Table 1).

Which site has the greatest habitat complexity?-We addressed this question based on four characteristics associated with Bull Trout habitat use. The Camas site contained the most stream area consisting of slow-water habitat $\left(9,798 \mathrm{~m}^{2}\right)$ and gravel substrate $\left(13,630 \mathrm{~m}^{2}\right)$ and the second-greatest total area comprised of coarse substrate $(4,364$ $\left.\mathrm{m}^{2}\right)$ and instream cover $\left(3,233 \mathrm{~m}^{2}\right.$; Table 2), resulting in a total score of 3 for these four criteria (Table 1). The Logging site had the greatest stream area comprised of coarse substrate 
$\left(11,514 \mathrm{~m}^{2}\right)$ and instream cover $\left(10,307 \mathrm{~m}^{2}\right)$ and the secondgreatest area consisting of slow-water habitat $\left(8,520 \mathrm{~m}^{2}\right)$ and gravel substrate $\left(11,080 \mathrm{~m}^{2}\right.$; Table 2$)$, resulting in a total score of 3 for the four criteria (Table 1). Concurrently, the Lincoln site received a total score of 0 for these criteria, having the least amount of slow-water habitat $\left(398 \mathrm{~m}^{2}\right)$, gravel substrate $\left(571 \mathrm{~m}^{2}\right)$, coarse substrate $\left(1,020 \mathrm{~m}^{2}\right)$, and instream cover $(393$ $\mathrm{m}^{2}$ ) among the proposed sites (Tables 1,2).

Which site contains the greatest quantity of habitat?-The total amount of stream and lake habitat varied across study sites (Table 3). Among the three sites, the Lincoln site had the least amount of stream habitat $\left(1,838 \mathrm{~m}^{2}\right)$ but had the greatest lake surface area (69 ha) and maximum depth $(>90 \mathrm{~m})$, resulting in a total score of 2 for the three criteria (Tables 1, 3 ). The Logging site had the greatest amount of stream habitat $\left(24,625 \mathrm{~m}^{2}\right)$, the second-largest lake surface area (33 ha), and the shallowest maximum depth $(15 \mathrm{~m})$, resulting in a total score of 1.5 for these three criteria (Tables 1,3). The Camas site had the second-greatest maximum depth $(85 \mathrm{~m})$, the second-greatest amount of stream habitat $\left(20,283 \mathrm{~m}^{2}\right)$, and the least amount of lake surface area (29 ha), resulting in a total score of 1 for these criteria (Tables 1, 3).

\section{Assessment of the Recipient Community}

Will the introduction have adverse impacts on other sensitive aquatic species?-This question addresses the concern that Bull Trout introduction could result in the localized decline or extirpation of other sensitive aquatic species. There were no threatened, endangered, or otherwise sensitive species detected during sampling at the Lincoln site, resulting in a score of 1 (highly suitable) for that site (Table 1). However, boreal toads Bufo boreas boreas were detected at both the Camas and Logging sites, resulting in a score of -1 (low suitability) for both sites (Table 1). The boreal toad is classified as a species of special concern in Montana due to potential declines in habitat and abundance (Montana Natural Heritage Program 2013); therefore, indirect effects (e.g., habitat modifications and changes in prey availability) resulting from Bull Trout introduction could impact local boreal toad populations.
TABLE 2. Physical stream characteristics of the three proposed sites of Bull Trout translocation in Glacier National Park. Each site consisted of a streamand-lake network within the Camas, Lincoln, or Logging Creek drainage. Values represent total stream area $\left(\mathrm{m}^{2}\right)$ comprised of each habitat characteristic.

\begin{tabular}{lccr}
\hline \multirow{4}{*}{$\begin{array}{l}\text { Physical habitat } \\
\text { characteristic }\end{array}$} & Camas & Lincoln & Logging \\
\cline { 2 - 4 } & Habitat type \\
Pool & 1,199 & 237 & 4,331 \\
Glide & 8,599 & 161 & 4,189 \\
Riffle & 6,574 & 947 & 16,101 \\
Cascade & 3,912 & 493 & 5 \\
\multicolumn{4}{c}{ Substrate } \\
Sand/silt & 1,254 & 0 & 1,879 \\
Gravel & 13,630 & 571 & 11,080 \\
Cobble & 2,467 & 665 & 8,087 \\
Boulder & 1,897 & 355 & 3,427 \\
Bedrock & 1,035 & 248 & 153 \\
& Instream cover & & \\
Large woody debris & 625 & 262 & 3,609 \\
Undercut bank & 112 & 0 & 589 \\
Boulder & 720 & 0 & 2,361 \\
Overhanging vegetation & 1,776 & 131 & 2,732 \\
Backwater & 0 & 0 & 1,016 \\
\hline
\end{tabular}

Is the existing aquatic community compatible with Bull Trout?-This question was developed to address any possible threats to Bull Trout through competition or hybridization with other species. The nonnative Yellowstone Cutthroat Trout Oncorhynchus clarkii bouvieri was the only fish species detected at both the Camas and Logging sites, resulting in a score of 1 (high suitability) for each site (Table 1). Although the historic distributions of Bull Trout and Yellowstone Cutthroat Trout do not overlap, the two species exist in sympatry in other systems within Glacier National Park (Morton 1968; Marnell et al. 1987). In contrast, the nonnative Brook Trout Salvelinus fontinalis was the only fish species detected at the Lincoln site,

TABLE 3. Surface area and maximum depth of lakes and the total length and area of streams within each proposed site of Bull Trout translocation in Glacier National Park. Each site consisted of a stream-and-lake network within the Camas, Lincoln, or Logging Creek drainage.

\begin{tabular}{llcccc}
\hline Water body & Study site & Surface area (ha) & Maximum depth $(\mathrm{m})$ & Stream length $(\mathrm{m})$ & Stream area $\left(\mathrm{m}^{2}\right)$ \\
\hline Camas Lake & Camas & 7 & 9 & & \\
Lake Evangeline & Camas & 29 & 85 & & \\
Lake Ellen Wilson & Lincoln & 69 & $>90^{\mathrm{a}}$ & & 20,283 \\
Grace Lake & Logging & 33 & 15 & 2,767 & 1,838 \\
Camas Creek & Camas & & & 278 & 24,625 \\
Lincoln Creek & Lincoln & & & 3,093 & \\
Logging Creek & Logging & & & & \\
\hline
\end{tabular}

${ }^{\mathrm{a}}$ Actual maximum depth was not measurable due to equipment limitations. 
resulting in a score of -1 (low suitability) for this question (Table 1). Brook Trout may hybridize with Bull Trout (Leary et al. 1983; Kanda et al. 2002) and have been shown to exhibit a competitive advantage over Bull Trout in natural and laboratory settings (Gunckel et al. 2002; McMahon et al. 2007). Thus, Bull Trout introduction to the Lincoln site would have to be preceded by Brook Trout eradication via piscicides or alternate removal methods (e.g., netting or redd excavation).

\section{Assessment of the Donor Population}

Is the donor population robust to the removal of propagules? This question addresses the concern that removal of propagules for translocation may jeopardize the persistence of the donor population. Past research has estimated Bull Trout relative abundances downstream of the Camas site at $0.52 \mathrm{fish} /$ net-hour in Trout Lake and 0.29 fish/net-hour in Arrow Lake (Meeuwig and Guy 2007). These catch rates suggest that Bull Trout densities downstream of the Camas site are comparable to those of other uninvaded, self-sustaining Bull Trout populations in Glacier National Park and that the population is likely robust to the removal of propagules for introduction (Meeuwig and Guy 2007). Therefore, the Camas site received a score of 1 (highly suitable) for this criterion (Table 1). Conversely, relative abundance downstream of the Lincoln site was estimated at $0.057 \mathrm{fish} /$ net-hour, and relative abundance downstream of the Logging site was estimated at 0.029 fish/net-hour (Meeuwig and Guy 2007). Therefore, both the Lincoln and Logging sites received a score of -1 (low suitability) for this criterion, indicating that the removal of propagules from either of these donor populations could jeopardize their long-term persistence (Table 1).

Does the donor population contain sufficient genetic diversity?-This question was designed to increase the likelihood of success by maximizing the adaptive potential of translocated individuals. Estimates of genetic heterozygosity in Bull Trout populations downstream of the Lincoln and Logging sites were greater than 0.5 (Meeuwig and Guy 2007), resulting in a score of 1 (high suitability) for each of those sites (Table 1). Conversely, genetic heterozygosity for Bull Trout downstream of the Camas site was estimated at 0.21 (Meeuwig and Guy 2007). Therefore, the Camas site received a score of -1 (low suitability) for this question, as heterozygosity in the donor population was similar to that of other isolated Bull Trout populations in Glacier National Park (Meeuwig and Guy 2007).

Is the life history strategy of the donor population compatible?-This question was developed to address the concern that introduction sites might not support a population of Bull Trout exhibiting specific life history strategies. All three sites received a score of 1 for this component (highly suitable) because Bull Trout populations downstream of each site exhibit a lacustrine-adfluvial life history strategy (Table 1). Each site consists of a stream-and-lake network that could support a population exhibiting this life history strategy. Although stream habitat is very limited at the Lincoln site, that characteristic was accounted for in the ranking of sites based on total stream area and was not considered when scoring this component.

\section{Assessment of Future Threats}

This component addresses future threats that could jeopardize Bull Trout persistence and could lead to the failure of an introduction. The three evaluated sites are unusual in that they are found within the borders of Glacier National Park, and many potential threats from habitat modifications and social and economic changes are nonexistent given the protected nature of the park. As such, all three sites received a score of 1 (highly suitable) for these two criteria (Table 1).

The three sites are also unusual in that all are situated within natal drainages above natural fish passage barriers in backcountry wilderness areas. Therefore, the threat posed by nonnative species invasions (both natural and human mediated) is minimal given that the upstream movement of species is highly unlikely; each site received a score of 1 (highly suitable) for this criterion (Table 1). Furthermore, previous guidelines suggest that the translocation of wild stock between areas within a single drainage presents a low risk of transferring new parasites or diseases given the proximity and connectedness of the donor stock with the introduction site (Williams et al. 1988); thus, each site received a score of 1 for this criterion (Table 1). However, all three sites received a score of -1 (low suitability) relating to the dispersal of Bull Trout outside of the introduction site, as it would be possible for Bull Trout to pass over the barrier at the downstream limit of each site. Such dispersal could jeopardize the success of the introduction by reducing Bull Trout density at the recipient site. Concurrently, each site was given a score of 1 (highly suitable) based on the likelihood that dispersal could result in Bull Trout establishment outside of the introduction site, as each site is geographically isolated in a headwater drainage upstream of the potential donor population (Table 1). Introduced fish are only able to emigrate downstream, which would result in their return to the original capture location.

Will sites remain thermally suitable under future climate change?-Bull Trout are among the most thermally sensitive freshwater species in North America (Selong et al. 2001) and are predicted to be particularly vulnerable to stream temperature increases induced by climate warming (Rieman et al. 2007; Wenger et al. 2013; Jones et al. 2014). Using a spatial hierarchical model to predict future temperatures throughout the streams in each recipient habitat, we estimated that the future mean August stream temperature for habitats at the Lincoln site would be less than $13^{\circ} \mathrm{C}\left(12.6^{\circ} \mathrm{C}\right)$, whereas the Logging and Camas sites were predicted to have average summer temperatures less than $14^{\circ} \mathrm{C}\left(13.9^{\circ} \mathrm{C}\right.$ and $13.7^{\circ} \mathrm{C}$, respectively). Consequently, the Lincoln site received a score of 1 (highly suitable) and the Logging and Camas sites each received a score of 0.5 (moderately suitable) for this criterion (Table 1). 


\section{Overall Ranking}

Based on this framework, the Logging site was identified as being the most suitable for Bull Trout introduction, receiving an overall score of 11.5 (Table 4). The Logging site contains suitable habitat, its biotic community is compatible with Bull Trout, and dangers imposed by future threats are minimal. Concurrently, the Camas site was found to be the secondmost suitable site for introduction, with an overall score of 11.0 (Table 4). The Camas site also contains suitable habitat, has a biotic community that is compatible with Bull Trout, and has minimal risk imposed by future threats. However, in each case, the within-drainage translocation of Bull Trout does face some obstacles. The Bull Trout population downstream of the Camas site exhibits genetic heterozygosity estimates that are representative of isolated populations, possibly limiting the adaptive potential of Bull Trout in that drainage. The Bull Trout population downstream of the Logging site exhibits low relative abundance and thus could be jeopardized by the removal of propagules for translocation.

The Lincoln site is ranked least suitable for Bull Trout introduction, with an overall score of 9.5. Two major differences account for the discrepancy between the Lincoln site and the Logging and Camas sites. First, the quantity of stream habitat available at the Lincoln site is extremely limited. Second, the presence of nonnative Brook Trout poses a threat to Bull Trout persistence through hybridization and competition (Leary et al. 1983; Gunckel et al. 2002; Kanda et al. 2002; McMahon et al. 2007). Furthermore, the relative abundance of Bull Trout downstream of the Lincoln site is low, suggesting that the removal of propagules could jeopardize the donor population's persistence.

\section{Further Considerations}

Recent IUCN guidelines (IUCN 2013) draw attention to the risks and uncertainties that are implicit in translocation, and there is a growing debate concerning the appropriateness of conservation introductions. Questions regarding the ethics of translocation exist due to the associated uncertainties as well as the unintended negative consequences that have resulted from past attempts, including the decline or extirpation of native species and the establishment of invasive species (Mueller and Hellmann 2008; Ricciardi and Simberloff 2009; Minteer and Collins 2010). However, if conducted appropriately, translocation can be a valuable tool for the conservation of threatened or imperiled species (Hunter 2007; McLachlan et al. 2007; Loss et al. 2011; Olden et al. 2011; Thomas 2011; Pérez et al. 2012). We argue that in appropriate situations, conservation introduction can serve as a valuable tool for conserving threatened populations by creating new populations in areas of refugia from existing and future stressors.

We used empirical habitat and population data in conjunction with a feasibility framework to address some of the uncertainties and risks associated with the conservation introduction of native
TABLE 4. Major component scores, overall suitability scores, and suitability rankings for each proposed site of Bull Trout translocation in Glacier National Park. Each site consisted of a stream-and-lake network within the Camas, Lincoln, or Logging Creek drainage.

\begin{tabular}{lccc}
\hline & \multicolumn{3}{c}{ Site } \\
\cline { 2 - 4 } Major component & Camas & Lincoln & Logging \\
\hline Recipient habitat & 5.5 & 3.5 & 6.0 \\
Recipient community & 0 & 0 & 0 \\
Donor population & 1 & 1 & 1 \\
Future threats & 4.5 & 5.0 & 4.5 \\
Overall score & 11.0 & 9.5 & 11.5 \\
Suitability ranking & 2 & 3 & 1 \\
\hline
\end{tabular}

Bull Trout into isolated stream and lake habitats. We minimized risks by (1) determining whether sensitive species were likely present in the potential recipient stream and lake habitats and (2) restricting introduction to headwater drainages where dispersal would be limited to downstream emigration and would be acceptable, as the Bull Trout donor population was downstream of each proposed site. We also evaluated potential threats associated with nonnative species invasions, future habitat modifications, increases in stream temperature due to climate warming, and future social and economic pressures that could cause the sites to become unsuitable for Bull Trout in the future. Future applications of this framework should attempt to reduce the uncertainties and risks associated with conservation introductions where feasible.

Our scoring procedure utilized empirical data for criteria that influence successful Bull Trout introduction to help managers assess the risk and prioritize conservation actions within Glacier National Park. Data were (1) classified according to constructed scales (e.g., high, moderate, and low suitability) that were then converted to numerical scores $(1,0.5,-0.5$, and -1$)$ or (2) ranked according to the total quantity of habitat available, thereby providing a simple interpretation of site suitability for Bull Trout. However, ordinal numbers do not necessarily reflect the magnitude of differences among sites, and the conservation action that is ultimately selected can be influenced by the choice of criteria included in the framework. We implemented this scoring procedure to provide a simple way of assessing the relative suitability of sites and to maintain focus on the development of framework criteria and implementation. Alternative scoring methods, such as a probability-based scoring system or a Bayesian belief network, may be more effective at addressing uncertainty in estimates and highlighting the magnitude of differences between sites.

Conservation introductions present difficult and complex decisions that resource managers must address in the face of uncertainty. Structured decision making in natural resource management includes three basic components: (1) identification of the explicit resource objectives, (2) identification of management alternatives that can be implemented to meet 
the resource objectives, and (3) development of alternative models that can be used to assess the effects of management actions on resource objectives (Conroy and Peterson 2013). Although sophisticated modeling approaches to decision making in natural resource management are available (Conroy and Peterson 2013), we chose to develop a relatively simple model framework and scoring system to assist natural resource managers in identifying management sites (i.e., management alternatives) that would be most likely to support successful conservation introductions of freshwater fishes (i.e., resource objectives). Therefore, we recommend that in addition to implementing this framework, more rigorous and quantitative analyses (e.g., population and community models) should be incorporated to assess the uncertainty, risks, and likelihood of success associated with various translocation alternatives. Furthermore, expert panel discussions may be beneficial when uncertainty exists and when multiple stakeholders are likely to be affected by introduction. Similar analyses were conducted prior to reintroduction of Bull Trout in the Clackamas River, Oregon (Lowery and Beauchamp 2010; Marcot et al. 2012).

We stress that this framework is intended to be used only as a tool for evaluating the feasibility of conducting conservation introductions; managers should temper these results by applying sound judgment to determine whether translocation is an appropriate conservation action given the unique situation to which it is applied. The framework outlines a relatively simplistic approach to identify sites that are most suitable for translocation based on 21 individual criteria. Although the overall score is useful in identifying the most suitable sites, managers should not overlook scores for individual criteria when analyzing the framework's results. There are likely to be instances in which a site has a high overall score but is not suitable for translocation given the scores it receives for specific individual criteria (e.g., the site contains an invasive species that would jeopardize the persistence of the introduced species). In some cases, translocation into moderately suitable sites may be warranted given the direness of the situation or the lack of feasible conservation alternatives (e.g., genetic rescue).

This framework is intended to be used as an outline for managers in assessing the feasibility of conducting conservation introductions of threatened species. It is our intent that managers will populate this framework with criteria that are critical to the survival and persistence of other threatened species. Other factors that were not addressed in this framework but that could influence conservation introductions of threatened fishes include streamflow, hyporheic exchange, substrate embeddedness, water quality, dissolved oxygen, and rates of primary productivity, among others. Thresholds for evaluating site suitability based on these factors could be easily integrated into the framework.

Monitoring is essential for conducting a successful translocation, and an effective, objective-driven monitoring program must be in place prior to any conservation action. Monitoring can focus on estimating population dynamics (e.g., abundance, survival, reproductive effort and success, juvenile recruitment, dispersal, etc.), impacts to native species and ecosystem function, and any social and economic changes that result from the introduction (USFWS et al. 2011; IUCN 2013).

\section{Current Applications}

Resource managers have recently used the results from this study as the basis for the first conservation introduction of Bull Trout in Glacier National Park and (to our knowledge) in the upper Columbia River drainage (Galloway 2014). Fisheries biologists concluded that a conservation introduction of Bull Trout into the Logging site was the best management option considering the site's overall score and the imperiled state of the Bull Trout population in Logging Lake. Therefore, in 2014, 111 juvenile Bull Trout were captured via electrofishing in Logging Creek downstream of the Logging site and were transported upstream into formerly unoccupied habitat (Downs et al. 2015). Future work will focus on increasing the number of translocated individuals and monitoring their performance through time.

\section{ACKNOWLEDGMENTS}

We are grateful to T. Pederson, V. D'Angelo, B. Miller, A. White, and C. Fredenberg for field assistance and J. Giersch for production of manuscript figures. Funding for the project was provided by the U.S. Geological Survey and the U.S. Fish and Wildlife Service through the Science Support Partnership. Any use of trade, firm, or product names is for descriptive purposes only and does not imply endorsement by the U.S. Government.

\section{REFERENCES}

Allendorf, F. W., and R. F. Leary. 1986. Heterozygosity and fitness in natural populations of animals. Pages 57-76 in M. E. Soule, editor. Conservation biology. Sinauer, Sunderland, Massachusetts.

Brooks, J. E. 1985. Factors affecting the success of Gila Topminnow (Poeciliopsis o. occidentalis) introductions on four Arizona national forests. Arizona Game and Fish Department, Phoenix.

Carlisle, D. M., and C. P. Hawkins. 1998. Relationships between invertebrate assemblage structure, two trout species, and habitat structure in Utah mountain lakes. Journal of the North American Benthological Society 17:286-300.

Conroy, M. J., and J. T. Peterson. 2013. Decision making in natural resource management: a structured, adaptive approach. Wiley, Hoboken, New Jersey.

D’Angelo, V. S. 2010. Factors influencing the distribution of Bull Trout and Westslope Cutthroat Trout west of the Continental Divide in Glacier National Park. Master's thesis. University of Montana, Missoula.

D'Angelo, V. S., and C. C. Muhlfeld. 2013. Factors influencing the distribution of native Bull Trout and Westslope Cutthroat Trout in streams of western Glacier National Park, Montana. Northwest Science 87:1-11.

DeHaan, P. W., B. Adams, W. A. Fredenberg, and B. Gardner. 2011. Identification of population origin for Bull Trout captured in Swan Lake, Montana. U.S. Fish and Wildlife Service, Final Report, Longview, Washington. 
DeHaan, P. W., M. Diggs, and W. R. Ardren. 2008. Analysis of genetic variation in Metolius River basin Bull Trout populations. U.S. Fish and Wildlife Service, Final Report, Bend, Oregon.

DeHaan, P. W., L. Godfrey, D. Peterson, and D. Brewer. 2010. Bull Trout population genetic structure and entrainment in Warm Springs Creek, Montana. U.S. Fish and Wildlife Service, Final Report, Helena, Montana.

Downs, C. C., C. R. Fredenberg, V. S. D’Angelo, C. C. Muhlfeld, and B. McKeon. 2015. Glacier National Park fisheries monitoring and management report, 2014. National Park Service, West Glacier, Montana.

Downs, C. C., N. Muhn, and B. McKeon. 2013. Glacier National Park fisheries inventory and monitoring report, 2013. National Park Service, Glacier National Park, West Glacier, Montana.

Dunham, J. B., K. Gallo, D. Shively, C. Allen, and B. Goehring. 2011. Assessing the feasibility of native fish reintroductions: a framework applied to threatened Bull Trout. North American Journal of Fisheries Management 31:106-115.

Dunham, J. B., and B. E. Rieman. 1999. Metapopulation structure of Bull Trout: influences of physical, biotic, and geometrical landscape characteristics. Ecological Applications 9:642-655.

Dunham, J. B., B. E. Rieman, and G. Chandler. 2003. Influences of temperature and environmental variables on the distribution of Bull Trout within streams at the southern margin of its range. North American Journal of Fisheries Management 23:894-904.

Eby, L. A., W. J. Roach, L. B. Crowder, and J. A. Stanford. 2006. Effects of stocking-up freshwater food webs. Trends in Ecology and Evolution 21:576-584.

Fraley, J. J., and B. B. Shepard. 1989. Life history, ecology and population status of migratory Bull Trout (Salvelinus confluentus) in the Flathead Lake and River system, Montana. Northwest Science 63:133-143.

Fredenberg, W. A. 2002. Further evidence that Lake Trout displace Bull Trout in mountain lakes. Intermountain Journal of Sciences 8:143-152.

Fredenberg, W. A., M. H. Meeuwig, and C. S. Guy. 2007. Action plan to conserve Bull Trout in Glacier National Park, Montana. U.S. Fish and Wildlife Service, Kalispell, Montana.

Galloway, B. T. 2014. Feasibility assessment for the translocation of imperiled Bull Trout populations in Glacier National Park, Montana. Master's thesis. Montana State University, Bozeman.

Gunckel, S. L., A. R. Hemmingsen, and J. L. Li. 2002. Effect of Bull Trout and Brook Trout interactions on foraging habitat, feeding behavior, and growth. Transactions of the American Fisheries Society 131:1119-1130.

Hankin, D. G., and G. H. Reeves. 1988. Estimating total fish abundance and total habitat area in small streams based on visual estimation methods. Canadian Journal of Fisheries and Aquatic Sciences $45: 834-844$.

Harig, A. L., K. D. Fausch, and M. K. Young. 2000. Factors influencing success of Greenback Cutthroat Trout translocations. North American Journal of Fisheries Management 20:994-1004.

Hecnar, S. J., and R. T. M'Closkey. 1997. The effects of predatory fish on amphibian species richness and distribution. Biological Conservation 79:123-131.

Hendrickson, D. A., and J. E. Brooks. 1991. Transplants of short-lived fishes of southwest North American deserts-a review, assessment and recommendations. Pages 283-298 in W. L. Minckley and J. E. Deacon, editors. Battle against extinction: desert fish management in the American Southwest. University of Arizona Press, Tucson.

Holderegger, R., U. Kamm, and F. Gugerli. 2006. Adaptive vs. neutral genetic diversity: implications for landscape genetics. Landscape Ecology 21:797-807.

Hunter, M. L. 2007. Climate change and moving species: furthering the debate on assisted colonization. Conservation Biology 21:1356-1358.

IUCN (International Union for Conservation of Nature). 2013. Guidelines for reintroductions and other conservation translocations. IUCN, Species Survival Commission, Gland, Switzerland.
Jones, L. A. 2012. Using a spatially explicit stream temperature model to assess potential effects of climate warming on Bull Trout habitats. Master's thesis. Montana State University, Bozeman.

Jones, L. A., C. C. Muhlfeld, L. A. Marshall, B. L. McGlynn, and J. L. Kershner. 2014. Estimating thermal regimes of Bull Trout and assessing the potential effects of climate warming on critical habitats. River Research and Applications 30:204-216.

Kanda, N., R. F. Leary, F. W. Allendorf. 2002. Evidence of introgressive hybridization between Bull Trout and Brook Trout. Transactions of the American Fisheries Society 131:772-782.

Knapp, R. A., P. S. Corn, and D. E. Schindler. 2001a. The introduction of nonnative fish into wilderness lakes: good intentions, conflicting mandates, and unintended consequences. Ecosystems 4:275-278.

Knapp, R. A., and K. R. Matthews. 2000. Non-native fish introductions and the decline of the mountain yellow-legged frog from within protected areas. Conservation Biology 14:428-438.

Knapp, R. A., K. R. Matthews, and O. Sarnelle. 2001b. Resistance and resilience of alpine lake fauna to fish introductions. Ecological Monographs 71:401-421.

Kovach, R. P., C. C. Muhlfeld, A. A. Wade, B. K. Hand, D. C. Whited, P. W. DeHaan, R. Al-Chokhachy, and G. Luikart. 2015. Genetic diversity is related to climatic variation and vulnerability in threatened Bull Trout. Global Change Biology 21:2510-2524.

Leary, R. F., F. W. Allendorf, and K. L. Knudsen. 1983. Consistently high meristic counts in natural hybrids between Brook Trout and Bull Trout. Systematic Zoology 32:369-376.

Loss, S. R., L. A. Terwilliger, and A. C. Peterson. 2011. Assisted colonization: integrating conservation strategies in the face of climate change. Biological Conservation 144:92-100.

Lowery, E. D., and D. A. Beauchamp. 2010. Baseline food web assessment of the upper Clackamas River basin prior to reintroduction of Bull Trout. U. S. Geological Survey, Washington Cooperative Fish and Wildlife Research Unit, School of Aquatic and Fisheries Sciences, University of Washington, Report WACFWRU-010-02, Seattle.

Marcot, B. G., C. S. Allen, S. Morey, D. Shively, and R. White. 2012. An expert panel approach to assessing potential effects of Bull Trout reintroduction on federally listed salmonids in the Clackamas River, Oregon. North American Journal of Fisheries Management 32:450-465.

Marnell, L. F. 1997. Herpetofauna of Glacier National Park. Northwestern Naturalist 78:17-33.

Marnell, L. F., R. J. Behnke, and F. W. Allendorf. 1987. Genetic identification of Cutthroat Trout, Salmo clarki, in Glacier National Park, Montana. Canadian Journal of Fisheries and Aquatic Sciences 44:1830-1839.

Martinez, P. J., P. E. Bigelow, M. A. Deleray, W. A. Fredenberg, B. S. Hansen, N. J. Horner, S. K. Lehr, R. W. Shneidervin, S. A. Tolentino, and A. E. Viola. 2009. Western Lake Trout woes. Fisheries 34:424-442.

McDowell, R. M. 2003. Impacts of introduced salmonids on native galaxiids in New Zealand upland streams: a new look at an old problem. Transactions of the American Fisheries Society 132:229-238.

McLachlan, J. S., J. J. Hellmann, and M. W. Schwartz. 2007. A framework for debate of assisted migration in an era of climate change. Conservation Biology 21:297-302.

McMahon, T. E., A. V. Zale, F. T. Barrows, J. H. Selong, and R. J. Danehy. 2007. Temperature and competition between Bull Trout and Brook Trout: a test of the elevation refuge hypothesis. Transactions of the American Fisheries Society 136:1313-1326.

McPhail, J. D., and C. B. Murray. 1979. The early life history and ecology of Dolly Varden (Salvelinus malma) in the upper Arrow Lakes. University of British Columbia, Manuscript Report 113, Vancouver.

Meeuwig, M. H., and C. S. Guy. 2007. Evaluation and action plan for protection of 15 threatened adfluvial populations of Bull Trout in Glacier National Park, Montana. U.S. Fish and Wildlife Service, Final Scientific Report, Kalispell, Montana. 
Meeuwig, M. H., C. S. Guy, and W. A. Fredenberg. 2007. Research summary for action plan to conserve Bull Trout in Glacier National Park, Montana. U.S. Fish and Wildlife Service, Kalispell, Montana.

Meeuwig, M. H., C. S. Guy, and W. A. Fredenberg. 2008. Influence of landscape characteristics on fish species richness among lakes of Glacier National Park, Montana. Intermountain Journal of Sciences $14: 1-16$.

Meeuwig, M. H., C. S. Guy, S. T. Kalinowski, and W. A. Fredenberg. 2010. Landscape influences on genetic differentiation among Bull Trout populations in a stream-lake network. Molecular Ecology 19:3620 3633.

Minckley, W. L. 1995. Translocation as a tool for conserving imperiled fishes: experiences in western United States. Biological Conservation 72:297-309.

Minteer, B. A., and J. P. Collins. 2010. Move it or lose it? The ecological ethics of relocating species under climate change. Ecological Applications 20:1801-1804.

Montana Natural Heritage Program. 2013. Species of concern. Available: www.mtnhp.org/speciesofconcern/. (October 2012).

Morton, W. M. 1968. A review of all fishery data obtained from waters of the North Fork Fishery Management Unit for the fifty-year period from 1916 through 1966, Glacier National Park, Montana. U.S. Fish and Wildlife Service, Review Report 8, Portland, Oregon.

Mueller, J. M., and J. J. Hellmann. 2008. An assessment of invasion risk from assisted migration. Conservation Biology 22:562-567.

Muhlfeld, C. C., and B. Marotz. 2005. Seasonal movement and habitat use by subadult Bull Trout in the upper Flathead River system, Montana. North American Journal of Fisheries Management 25:797-810.

Nyce, L. G., L. A. Eby, C. G. Clancy, S. Painter, and R. F. Leary. 2013. Genetic population structure of Bull Trout in the East Fork Bitterroot River drainage, Montana. North American Journal of Fisheries Management 33:432-445.

Olden, J. D., J. M. Kennard, J. J. Lawler, and N. L. Poff. 2011. Challenges and opportunities in implementing managed relocation for conservation of freshwater species. Conservation Biology 25:40-47.

Pérez, I., J. D. Anadón, M. Díaz, G. G. Nicola, J. L. Tella, and A. Giménez. 2012. What is wrong with current translocations? A review and a decisionmaking proposal. Frontiers in Ecology and the Environment 10:494-501.

Reed, D. H., and R. Frankham. 2003. Correlation between fitness and genetic diversity. Conservation Biology 17:230-237.

Ricciardi, A., and D. Simberloff. 2009. Assisted colonization is not a viable conservation strategy. Trends in Ecology and Evolution 24:248-253.
Rich, C. F., T. E. McMahon, B. E. Rieman, and W. L. Thompson. 2003. Local-habitat, watershed, and biotic features associated with Bull Trout occurrence in Montana streams. Transactions of the American Fisheries Society $132: 1053-1064$.

Rieman, B. E., D. Isaak, S. Adams, D. Horan, D. Nagel, C. Luce, and D. Myers. 2007. Anticipated climate warming effects on Bull Trout habitats and populations across the interior Columbia River basin. Transactions of the American Fisheries Society 136:1552-1565.

Rieman, B. E., D. C. Lee, and R. F. Thurow. 1997. Distribution, status, and likely future trends of Bull Trout within the Columbia River and Klamath basins. North American Journal of Fisheries Management 17:1111-1125.

Rieman, B. E., and J. D. McIntyre. 1995. Occurrence of Bull Trout in naturally fragmented habitat patches of varied size. Transactions of the American Fisheries Society 124:285-296.

Selong, J. H., T. E. McMahon, A. V. Zale, and F. T. Barrows. 2001. Effect of temperature on growth and survival of Bull Trout, with application of an improved method for determining thermal tolerance in fishes. Transactions of the American Fisheries Society 130:1026-1037.

Thomas, C. D. 2011. Translocation of species, climate change, and the end of trying to recreate past ecological communities. Trends in Ecology and Evolution 26:216-221.

USFWS (U.S. Fish and Wildlife Service), Oregon Department of Fish and Wildlife, and U.S. Forest Service. 2011. Clackamas River Bull Trout reintroduction implementation, monitoring, and evaluation plan. USFWS, Portland, Oregon.

Watson, G., and T. W. Hillman. 1997. Factors affecting the distribution and abundance of Bull Trout: an investigation at hierarchical scales. North American Journal of Fisheries Management 17:237-252.

Wenger, S. J., D. J. Isaak, C. H. Luce, H. M. Neville, K. D. Fausch, J. B. Dunham, D. C. Dauwalter, M. K. Young, M. M. Elsner, B. E. Rieman, A. F. Hamlet, and J. E. Williams. 2011. Flow regime, temperature, and biotic interactions drive differential declines of trout species under climate change. Proceedings of the National Academy of Sciences of the USA 108:14175-14180.

Wenger, S. J., N. A. Som, D. C. Dauwalter, D. J. Isaak, H. M. Neville, C. H. Luce, J. B. Dunham, M. K. Young, K. D. Fausch, and B. E. Rieman. 2013. Probabilistic accounting of uncertainty in forecasts of species distributions under climate change. Global Change Biology 19:3343-3354

Williams, J. E., D. W. Sada, and C. D. William. 1988. American Fisheries Society guidelines for introductions of threatened and endangered fishes. Fisheries 13(5):5-11. 